\title{
Kształtowanie postawy patriotycznej w nauczaniu ks. prof. Jerzego Bajdy ${ }^{1}$
}

Wstęp

Podejmując zadania w nowym stuleciu, Kościół w Polsce jest świadom tego, że swoją kondycję moralną zawdzięcza pełnej poświęcenia pracy wielu wybitnych ludzi minionego i obecnego wieku. Niewątpliwie jedną z takich postaci naznaczających swoją wiedzą i zapałem apostolskim oblicze chrześcijańskiej moralności w Polsce drugiej połowy XX wieku i na początku XXI wieku był ks. prof. Jerzy Bajda. Przez wszystkie lata swojej pracy naukowej, $w$ trudnym okresie komunizmu i jego załamywania się, aż po czasy współczesne ks. Bajda przekazywał niezmienną Bożą prawdę i ewangeliczne zasady moralne. Jako naukowiec
- Wstęp

- Powinności moralne związane z miłością ojczyzny - Formacja patriotyczna - Zakończenie

1 Artykuł tegoż autora ukazał się w dużej części w czasopiśmie "Studia Gdańskie „ 39 (2016), s. 191-216. 
i duszpasterz, odpowiedzialny za formowanie i umacnianie życia moralnego, dawał konkretne wskazówki, jak należy żyć i co należy czynić, aby życie chrześcijańskie stawało się coraz doskonalsze. W swoich licznych publikacjach i wystąpieniach podejmował najbardziej aktualne zagadnienia i wyzwania ówczesnego czasu. Ks. Bajda pragnął wyjść naprzeciw wszystkiemu, co niósł ze sobą współczesny świat, by przyczynić się do właściwego ukształtowania życia moralnego chrześcijan.

W przekazywanym przez ks. Bajdę orędziu moralnym nie mogło więc zabraknąć odniesień do życia społecznego. W całokształcie problematyki społecznej, którą ks. Bajda podjął w swoim nauczaniu, można odnaleźć zagadnienia o kluczowym znaczeniu dla życia społecznego. Do istotnych zagadnień oprócz szeroko pojętej tematyki małżeńsko-rodzinnej - trzeba bez wątpienia zaliczyć także kształtowanie postawy patriotycznej. Zabiegając usilnie o odnowę życia społecznego, ks. Bajda pragnął, aby moralnie zdrowe społeczeństwo kształtowało odpowiedzialnych i wrażliwych na miłość ojczyzny obywateli.

Trzeba stwierdzić, że podejmowanie przez ks. Bajdę w publikacjach naukowych i popularnonaukowych (np. felietony w „Naszym Dzienniku”) tematu patriotyzmu, czyli odpowiedzialności za ojczyznę, wniosło wiele ciekawych wskazówek i mądrych pouczeń2 ${ }^{2}$. Było to niezwykle ważne w sytuacji obecności Polski w Unii Europejskiej, zjednoczonej Europie ${ }^{3}$. Obecnie daje się bowiem łatwo zauważyć, że nowe pokolenie Polaków wzrasta w klimacie jakiejś pustki, zniechęcenia, osłabienia woli życia, duchowego wykorzenienia i braku wrażliwości na to, co znaczy „ojczyzna”, służba ojczyźnie, poświęcenie dla niej. Co więcej, mówienie o ojczyźnie i miłości ojczyzny wielu Polaków dzisiaj drażni. Wynika to nie tylko ze współczesnej alergii na patos i gołosłowność. Socjologowie sygnalizują, że wielu dzisiejszych Polaków, zwłaszcza młodych, zatrważająco nisko ocenia własny naród. Wielu z wyjeżdżających za granicę wstydzi się tego, że są Polakami. Chcąc więc mieć trwałą i znaczącą pozycję w Europie, należy promować własną ojczyznę. Nie może być mniej miłości do Polski, jeśli jest więcej Europy, bo wówczas Europa będzie uboższa o to dobro, które jest zakotwiczone w ojczyźnie naszej-Polsce.

2 Szerzej por.: Obrona i promocja rodziny. Zamyślenia Księdza Profesora Jerzego Bajdy, red. M. Kluz, J. Młyński, Sandomierz 2015.

3 Por. J. Bajda, Jan Paweł II - promotor rodziny - w kontekście procesów integracyjnych w Europie, "Studia nad Rodziną" 7 (2003) nr 2, s. 55-77; J. Bajda, Jutro Europy i świata, w: R. Buttiglione, Filozoficzne rozumienie Europy, Lublin 1997, s. 2-3. 
$\mathrm{W}$ tej perspektywie istotnym zadaniem na dzisiaj jest ukazanie na nowo bogactwa i wartości ojczyzny oraz moralnych aspektów i powinności związanych z patriotyzmem i - co wydaje się najważniejsze - nieustanne prowadzenie od najmłodszych lat dzieła wychowania do czci, szacunku i miłości do własnej ojczyzny i przyjaźni z innymi narodami. Te wszystkie tematy można odnaleźć w nauczaniu moralnym ks. prof. Bajdy. I należy zaznaczyć, że pisał o tych sprawach odważnie, zgłębiając najważniejsze problemy.

\section{Powinności moralne związane z miłością do ojczyzny}

Na pojęcie „ojczyzna” w doświadczeniu i przekazie ks. Bajdy składa się wiele wątków. Są nimi: ziemia, ludzie, rodzina, dzieje, historia, tradycja, język, religia, kultura. Ojczyzna jest dobrem fundamentalnym, „nośnikiem”' wielorakich wartości zarówno dla osoby jako jednostki, jak i dla wspólnoty osób. Ks. Bajda powołany do służby wartościom teologicznym i moralnym, widział ojczyznę również w perspektywie wiary. Ojczyzna jest dla niego darem Boga, Bożą tajemnicą. Ojczyzna jest także naszą matką, którą mamy obowiązek miłować. Stosuje się więc do niej prawo zawarte w IV przykazaniu. Obowiązek czci i miłości jawi się tu jako bezwarunkowy. W tej miłości zawiera się też postawa wdzięczności. Jako źródło bytu ludzkiego bowiem ojczyzna uczestniczy w wielkości i powadze Stwórcy. Ks. Bajda przypisał jej także pewne uczestnictwo w Chrystusowym dziele zbawczym i dziele uświęcania ludzi przez Ducha Świętego. Wprawdzie nadprzyrodzone dzieło zbawcze dokonuje się w Kościele i to on jest matką naszego zbawienia, niemniej jednak ojczyzna rodzi dzieci dla Kościoła oraz otwiera mu i toruje drogę do wykonywania właściwej misji i z tego tytułu zasługuje na głębszą cześć.

Ks. Bajda, mówiąc na temat ojczyzny, powoływał się na słowa Soboru Watykańskiego II, zawarte m.in. w dekrecie o działalności misyjnej Kościoła Ad gentes divinitus, zachęcającym chrześcijan, aby „żyjąc dla Boga i Chrystusa w uczciwej atmosferze swego narodu, jako dobrzy obywatele pielęgnowali prawdziwą i skuteczną miłość ojczyzny i unikali wszelkiej pogardy dla innej rasy oraz przesadnego nacjonalizmu"4. Podobną myśl wyraża Konstytucja duszpasterska o Kościele w świecie współczesnym Gaudium et spes: „Niech

4 Sobór Watykański II, Dekret o działalności misyjnej Kościoła Ad gentes divinitus, nr 15. 
obywatele pielęgnują wielkodusznie i wiernie miłość ojczyzny, jednak bez ciasnoty duchowej, tak by mieli również wzgląd na dobro całej rodziny ludzkiej”" Trzeba wyraźnie podkreślić, że Kościół, który czerpie inspiracje z Ewangelii Jezusa Chrystusa, od samego początku nauczał, że miłość ojczyzny jest obowiązkiem wszystkich chrześcijan. Obowiązek ten sięga tak daleko, że w pewnych warunkach może nawet wymagać złożenia ofiary z własnego życia.

Ks. Bajda, który pracował dla dobra Kościoła Chrystusowego, całym sercem starał się rozbudzić u wiernych poczucie odpowiedzialności za ojczyznę. Czynił to w niektórych swoich artykułach naukowych, a także felietonach publikowanych w „Naszym Dzienniku”. Ukazywał w nich potrzebę rozwijania zdrowego i autentycznego patriotyzmu. Uświadamiał, że chrześcijanin, który wsłuchuje się w słowa Pana i realizuje je w codziennym życiu, nie może przejść obojętnie wobec tego wszystkiego, co kryje się pod pojęciem ojczyzna. Pragnął więc, aby każdy chrześcijanin potrafił - wyrażając wdzięczność za wszelkie dobra otrzymane od społeczeństwa- szczerym sercem miłować swoją ojczyznę.

W czym praktycznie - zdaniem ks. Bajdy - ma się przejawiać prawdziwa miłość do ojczyzny, czyli zdrowy i autentyczny patriotyzm? Jest rzeczą oczywistą, że miłość ojczyzny nie polega wyłącznie na uczuciu. Wyżej więc niż więzi uczuciowe trzeba cenić miłość jako życzliwe nastawienie woli wobec ojczyzny - pragnienie dla niej prawdziwego dobra. Życzliwość ta kieruje się ostatecznie do ludzi, czyli do narodu, podstawowego elementu ojczyzny.

Zdaniem ks. Bajdy przejawem prawdziwej i autentycznej miłości ojczyzny nie są tylko piękne i uroczyste deklaracje słowne, ale przede wszystkim dobre czyny, praktyczne postawy. Dobre czyny i postawy mają uwidaczniać się szczególnie w solidnej pracy wykonywanej dla dobra wspólnego. Tylko praca bowiem, wytrwała i ofiarna, może zapewnić ojczyźnie pomyślność, dobrobyt, pokój i rozwój. Potrzeba dziś konkretnej służby dla dobra ojczyzny. Ta służba polega na poświęcaniu swoich sił, zdolności, troski i starań dobru wspólnoty, podporządkowaniu jej interesów osobistych ${ }^{6}$.

Według ks. prof. Bajdy świadectwem autentycznej miłości ojczyzny jest troska o jej pomyślny rozwój gospodarczy, społeczny, kulturalny, a także rozwój religijny i moralny. Dowodem prawdziwego patriotyzmu jest też troska

5 GS 75.

6 Por. S. Wyszyński, Służba matce ojczyźnie, w: Z dziejów polskiego patriotyzmu. Wybór tekstów, red. J. Kloczkowski, Kraków 2007, s. 320-333. 
o poprawne, życzliwe stosunki między ludźmi, szacunek dla wszystkich ludzi, nawet inaczej myślących, pochylanie się nad potrzebującymi, walka o sprawiedliwość i solidarność. Odpowiedzialność za ojczyznę oznacza również zakaz wyrządzania szkody własnemu narodowi i troskę o to, by nie czynili tego inni? ${ }^{7}$.

Szczególnym przejawem troski i odpowiedzialności człowieka za ojczyznę jest gotowość do składania dla niej ofiar. „Miłość - podkreślał ks. Bajda - potwierdza się przez gotowość ofiary" ${ }^{8} \mathrm{Im}$ większa będzie ofiarność, tym bardziej człowiek będzie mógł cieszyć się wraz z bliźnimi jej owocami. Kamieniem probierczym prawdziwej miłości ojczyzny będzie przede wszystkim gotowość do oddania za nią swojego życia. Czasy współczesne - jak uczył ks. Bajda - nie zawsze jednak wymagają od Polaków ofiary krwi, lecz nie mniejszego wysiłku w pracy codziennej oraz większego poczucia odpowiedzialności za ojczyznę. Należy więc postawić sobie wymagania uczciwego i szlachetnego życia, bezinteresowności, poszanowania godności każdego człowieka, umiłowania prawdy, wolności i pokoju oraz tych wszystkich wartości, które służą dobru człowieka i ojczyzny9

Prawdziwy patriotyzm zobowiązuje też człowieka do szacunku i wierności wobec dziedzictwa, któremu na imię „Polska”. Dziedzictwo jest wartością, której nie wymyślił człowiek. Jest to trwanie człowieka w określonym miejscu i uczestnictwo w określonych darach jako trwanie w darze stworzenia ${ }^{10}$. W nauczaniu ks. Bajdy słowo „dziedzictwo” pojawia się wielokrotnie. Jest ono filarem, fundamentem przekazu o ojczyźnie. Ma wymiar sacrum. W rozumieniu ks. Bajdy na podstawowe elementy dziedzictwa składają się: ziemia, dziedzictwo wiary, kultura i związana z nią tradycja oraz historia.

Związek z ziemią leży u podstaw dziedzictwa: „Abyście zaludnili ziemię i uczynili ją sobie poddaną" ( $\operatorname{Rdz} 1,28)$. Ziemię należy widzieć jako święty dar Boga. W niej odbija się świętość Boga. Ukazując ziemię jako święty dar Boga, należy apelować do rolników, aby z miłością stali przy ziemi, szanowali ją i bronili jej do ostatniej skiby. Wszyscy ludzie mają okazywać szacunek ziemi i uznawać godność pracujących na roli. Rolnicy bowiem żywią i bronią

7 Por. J. Salij, Patriotyzm dzisiaj, dz. cyt., s. 7-28.

8 J. Bajda, Rodzina miejscem Boga i człowieka, Łomianki 2005, s. 152.

9 Por. J. Bajda, Ku odnowionej Polsce, „Sprawy Rodziny” 73 (2006) nr 1, s. 94-102.

10 Por. J. Bajda, Feministki, papież i Europa, w: Obrona i promocja rodziny. Zamyślenia Księdza Profesora Jerzego Bajdy, red. M. Kluz, J. Młyński, Sandomierz 2015, s. 35-36. 
narodu. Pełnią zatem szczególną rolę w posiadaniu i utrzymaniu dziedzictwa. Rolnicy też stanowią element stałości i trwania. Owa stałość i trwanie wypływają z faktu posiadania ziemi i przekazywania jej następnym pokoleniom. Pozycja rolnika jest zatem jakby u samych podstaw dziedzictwa.

Idąc dalej, trzeba stwierdzić, że dziedzictwo to nie tylko podstawa bytu materialnego. Dziedzictwem na równi z ziemią, a może jeszcze bardziej, jest wszystko, co stanowi duchowy wymiar Polski. Polska - jak podkreślał ks. Bajda - to przede wszystkim dziedzictwo duchowe. Dlatego istotnym obowiązkiem obywateli jest troska o zachowanie tego dziedzictwa ${ }^{11}$. U podstaw dziedzictwa duchowego jest wiara. Wiara jest i zawsze była ostoją i ratunkiem dla narodu na trudnych drogach jego historii.

Trwała obecność wiary jest też nośnikiem polskiej tradycji. „Mamy swój honor i poczucie tożsamości, mamy swoją tradycję" - pisał w jednym z felietonów ks. Bajda ${ }^{12}$. Tradycja w ogólnym sensie oznacza sumę procesów i zwyczajów zdobytych i ustanowionych w historii i przekazywanych z pokolenia na pokolenie. Tradycja zapewnia ciągłość tego, co zostało rozpoczęte, zapewnia więc jakieś zasadnicze trwanie dziedzictwa. W przekazie ks. Bajdy tradycja oznacza odwołanie się do przeszłości z myślą o tym, co należy do „dziś, $\mathrm{z}$ troską o przyszłość. W tym też kontekście ks. Bajda uważał tradycję za podstawę rozwoju narodu ${ }^{13}$.

Przez swój chrześcijański charakter tradycja nosi znamiona świętości. Przynależność do świętego staje się bowiem podstawą moralnej świętości. Ten charakter świętości polskiej tradycji wskazuje, że jest ona konieczna i zarazem niepodważalna. Tylko to bowiem, co ma znamiona świętości, może zapewnić ludzkiemu życiu sens. W rozumieniu ks. Bajdy na tradycję polską składa się w szczególnej mierze wszystko to, co dotyczy kultu, a więc relacji do Boga, Maryi i świętych. Święta obchodzone w Polsce odznaczają się bogatą tradycją. Święta Bożego Narodzenia mają wymiar rodzinności i ludzkiej solidarności. Zbliżają ludzi do siebie i przez to obdarzają ich prawdziwym szczęściem. Również święto Zmartwychwstania Pańskiego ma specyficznie polską tradycję związaną z liturgią Wielkiego Tygodnia. W ten sam ciąg tradycji wpisał ks. Bajda uroczystość Bożego Ciała i tradycje świąt maryjnych. Do zapisu należy włączyć także polskie kolędy, pieśni religijne, Godzinki o Najświętszej

11 Por. Jan Paweł II, Pamięć i tożsamość, Kraków 2005, s. 66.

12 J. Bajda, Feministki, papież i Europa, dz. cyt., s. 36.

13 Por. J. Bajda, Ku odnowionej Polsce, dz. cyt., s. 96-97. 
Maryi Pannie. $Z$ ducha narodu zrodziły się też śpiewane w Wielkim Poście Gorzkie żale, których nie ma gdzie indziej. Godzinki są polskimi lamentacjami nad cierpieniem Boga za nas i nad naszą wobec Niego niewdzięcznością; w ciągu wieków były źródłem duchowej siły dla Polaków wystawionych na trudne i bolesne próby dziejowe ${ }^{14}$.

Tak więc można powiedzieć, że aby spłacić dług ojczyźnie, trzeba strzec w sobie i drugich ojczystego obyczaju. Tradycja i związana z nią obrzędowość jest spoiwem narodu. Powtarzalność obyczaju i obrzędu sprawia, że stanowią one czynnik utrwalania zbiorowości - zapewniają jej ciągłość. Tradycja należy do kategorii nakazu. Jest sposobem bycia człowieka i narodu, sposobem utrwalania dziedzictwa. Dziedzictwo związane z tradycją jest gruntem, na którym spotykają się różne pokolenia ${ }^{15}$.

W nauczaniu ks. Bajdy ważnym elementem dziedzictwa jest historia narodu, którą człowiek powinien kochać, szanować i zawsze o niej pamiętaćć Człowiek oderwany od przeszłości, historii więdnie i zamiera jak drzewo usychające od korzeni. Według ks. Bajdy, w historii ojczyzny pierwsze miejsce zajmuje Chrystus. On jest fundamentem bytu narodowego. „Niestety słabością Europy - jak twierdził Ksiądz Profesor - jest zagubienie więzi z Bogiem i tym samym utrata autentycznej podstawy moralności”17. Tymczasem bez Chrystusa nie można zrozumieć historii Polski, a także Europy ${ }^{18}$. Gdyby ktoś chciał oderwać Chrystusa od historii polskiej, dokonałby złego czynu, bo Chrystus przez wieki był źródłem największych wartości, które zostały urzeczywistnione w życiu polskiego narodu. Potwierdził to papież Jan Paweł II, mówiąc:

Nie sposób zrozumieć dziejów narodu polskiego - tej wielkiej tysiącletniej wspólnoty, która tak głęboko stanowi o mnie, o każdym z nas - bez

14 Por. W. Korzeniowska, Bogactwo i różnorodność tradycji w kulturze polskiej, w: Dziecko w świecie tradycji, t. VII, red. F. Ziemski, W. Korzeniowska, B. Dymara, Kraków 2002, s. 89-93.

15 Por. K. Chałas, S. Kowalczyk, Wychowanie ku wartościom narodowo-patriotycznym, t. II Naród. Ojczyzna. Patriotyzm. Państwo. Pokój, Lublin-Kielce 2006, s. 84-88.

16 Por. J. Bajda, Feministki, papież i Europa, dz. cyt., s. 93.

17 J. Bajda, Rodzina miejscem promocji godności osoby ludzkiej - w perspektywie przyszłości Europy, "Sprawy Rodziny" 77 (2007) nr 1, s. 56.

18 Por. J. Bajda, Jan Paweł II w Polsce (1997). Papieskie przesłanie dla Europy, "Ethos" 41-42 (1998), s. 109-118. Por. także: J. Bajda, Europa i „Człowiek”, w: Obrona i promocja rodziny..., dz. cyt., s. 231-233. 
Chrystusa. Jeślibyśmy odrzucili ten klucz dla zrozumienia naszego narodu, narazilibyśmy się na zasadnicze nieporozumienie ${ }^{19}$.

Chrystus był w narodzie i z narodem, zwłaszcza w chwilach trudnych doświadczeń. W ciągu tysiąca lat swojej historii Polacy niejednokrotnie odczuwali gorycz opuszczenia. Nigdy jednak nie byli osamotnieni. Zawsze bowiem był z nimi Chrystus ukrzyżowany, który przyciągał ich do swego serca swoją czułą miłością ${ }^{20}$.

W wymiarze ojczyzny z Chrystusem złączona jest Maryja ${ }^{21}$. Zdaniem ks. Bajdy specyfika polskiego chrześcijaństwa od początku dziejów polega na Maryjnej drodze wiary ${ }^{22}$. Królestwem Maryi było całe średniowieczne uniwersum, które swym charakterem naznaczyło również i dzieje Polski. Dzieje Polski zaczynają się od pieśni Bogurodzica. W tej najstarszej zachowanej polskiej pieśni religijnej zawarte są główne prawdy wiary i zasady moralności. Bogurodzica jest więc niejako dokumentem wiary, który trzeba wiernie zachowywać ${ }^{23}$.

Nieocenione jest znaczenie Jasnej Góry w życiu Polaków i ich doświadczeniu dziejów. Jakże zbawienne dla naszego narodu, nie tylko w czasie szwedzkiego potopu i szwedzkiej niewoli, lecz zawsze w ciągu długich wieków, okazywało się to, że był on w słodkiej niewoli Jasnogórskiej Pani. Słusznie nazywa się ta góra Jasną, bo z niej Niebieska Matka była dla narodu polskiego światłem nawet wtedy, gdy gasły wszystkie inne światła ${ }^{24}$. Obraz Jasnogórski odzwierciedla treść i doświadczenie wiary zawarte w pieśni Bogurodzica, a więc początek wiary i dziejów Polaków. Jasnogórski obraz posiada dla Polaków także wymiar moralnej wolności. Jan Paweł II mocno związany z Jasną Górą

19 Jan Paweł II, Homilia podczas Mszy św. na Placu Zwycięstwa (Warszawa, 2 czerwca 1979 r.), w: tenże, Nauczanie społeczne. Pielgrzymka do Polski 2-10 VI 1979, t. 1, Warszawa 1982, s. 21.

20 Por. J. Bajda, Wokół pewnego sporu, dz. cyt., s. 94.

21 Por. J. Bajda, Wokół pewnego sporu, dz. cyt., s. 94.

22 Por. J. Bajda, Rodzina miejscem Boga i człowieka..., dz. cyt., s. 153-158.

23 Por. A. Pawełczyńska, O istocie narodowej tożsamości. Polacy wobec zagrożeń, Lublin 2010, s. 99-101.

24 Papież Jan Paweł II przed przyjazdem do Polski na świętowanie sześćsetlecia obecności jasnogórskiej ikony w dziejach narodu, w modlitwie 25 sierpnia 1982, wypowiedział prawdę o tym, że „wizerunek jasnogórski jest trwałym wyrazem tego, jak historia naszego Narodu związała się z Maryją - i trwale z Nią wiąże", cyt. za: J. Nagórny, Moja Ojczyzna Ojczyzna Jana Pawła II, w: Z Karolem Wojtyłą myślq̨c Ojczyzna, red. W. Chudy, Lublin 2002 s. 193. 
stwierdził: „Tutaj zawsze byliśmy wolni”25. Można więc powiedzieć, że Jasna Góra jest miejscem, w którym niejako skoncentrowały się dzieje Polaków, historyczne doświadczenie chrześcijańskiego narodu. Polak-chrześcijanin kochający swoją ojczyznę musi o tym zawsze pamiętać.

Szczególnym znakiem Bożej obecności w historii ojczyzny są ludzie święci, bohaterowie zmagań na polach bitewnych, uczeni, literaci, politycy, a także ludzie „zwykli”, bezimienni, nieznani, starzy i młodzi. To im Polska zawdzięcza przetrwanie tylu groźnych burz dziejowych. Oni są najszlachetniejszym tworzywem i zwornikiem ojczystego dziedzictwa. To właśnie dzięki tym ludziom, bohaterom, dzięki ich ofierze Polska nie zginęła ${ }^{26}$. Dlatego o tej ofierze nie wolno nigdy zapomnieć - w imię nie tylko miłości, lecz nade wszystko sprawiedliwości. Czyny tych, którzy odeszli, są zatem zobowiązaniem dla potomnych.

Analizując nauczanie ks. Bajdy na temat dziedzictwa narodowego, można stwierdzić, że widział je on jako wielkie dobro Polaków. Dziedzictwo, które stanowi ojczyznę, jest zatem szczególną wartością, przedmiotem dążenia, gdyż to właśnie należy do istoty dobra. Jako dobro dziedzictwo to stanowi jednocześnie zobowiązanie do wierności i zadanie. Zadania wobec dziedzictwa wiążą się z powinnością moralną. Doświadczenia wartości bowiem nie można przyjąć bez odniesienia do powinności. Powinność ma zawsze charakter imperatywu moralnego wyrażającego się w sumieniu. Zadania wobec dziedzictwa mogą być więc najogólniej ujęte jako moralny imperatyw czynu patriotycznego ${ }^{27}$.

U źródeł tych zadan - zdaniem ks. Bajdy - leży przyjęcie dziedzictwa, związane z potwierdzeniem własnej tożsamości, a także moralną odpowiedzialnością za dar. Papież Jan Paweł II na Błoniach krakowskich w 1979 roku zobowiązał Polaków do przyjęcia dziedzictwa $z$ wiarą, nadzieją i miłością. Przyjęcie dziedzictwa oznacza więc wierność wartościom, które wraz z dziedzictwem zostały człowiekowi dane i zadane.

25 Jan Paweł II, Homilia w czasie Mszy św. odprawionej pod Szczytem Jasnej Góry (Częstochowa, 4 czerwca 1979), w: Jan Paweł II, Pielgrzymki do Ojczyzny. Przemówienia, homilie, Kraków 2005, s. 50.

26 Por. L. Elektorowicz, Pojęcie Ojczyzny - wczoraj i dziś, w: Z Karolem Wojtyła myślqac Ojczyzna, ds. 82-83.

27 Por. K. Ryczan, Wierność dziedzictwu a tożsamość narodowa, w: Szkoła miejscem kształtowania postawy patriotycznej, red. I. Skubiś, Częstochowa 1988, s. 9-25. 
O ile pozostajemy wierni nauczaniu Papieża - uświadamiał ks. Bajda mamy większe prawo nazywać się Europą niż ci, którzy odrzucili Boga i tym samym zdradzili prawa człowieka. Nie podzielam optymizmu tych, którzy twierdzą, że prawodawstwo unijne nie zagraża naszej suwerenności moralno-kulturowej ${ }^{28}$.

W tej perspektywie obowiązkiem moralnym człowieka jest nieustannie bronić dziedzictwa, czyli prawdy i prawa do tradycji, historii narodu i kultury ojczystej ${ }^{29}$. Obrona ta wiąże się również z obroną ładu moralnego w życiu osobistym, rodzinnym, zawodowym i społecznym. Dotyczy wszystkiego, co wiąże się z „korzeniami” dziedzictwa. Korzenie bowiem stanowią o możliwości życia i rozwoju. Drzewo nie może rozwijać się bez korzeni. Bez korzeni więdnie, usycha i zamiera. Podobnie człowiek, aby naprawdę mógł rozwijać się duchowo, musi pamiętać o korzeniach, z jakich wyrósł. Jeśli o swych korzeniach zapomina, grozi mu śmierć duchowa. Trzeba też pamiętać o tworzeniu dziedzictwa. W tym tworzeniu dziedzictwa można wyodrębnić dwa zasadnicze zadania: podstawowe idee przekazać następnym pokoleniom i wzbogacić dziedzictwo, czyli spowodować jego rozwój, dostosować wartości do potrzeb miejsca i czasu. To tworzenie dziedzictwa jest zarazem sposobem spłacenia długu, jaki zaciąga się wobec dziedzictwa.

Tak więc z nauczania ks. Bajdy wynika wyraźnie, że zadania wobec dziedzictwa mają dla człowieka moc imperatywu sumienia. Imperatywu, w którym polskość jest przedmiotem świadectwa, obowiązku i odpowiedzialności.

$\mathrm{Z}$ nauczania ks. Bajdy wynika ponadto, że prawdziwa troska i odpowiedzialność za ojczyznę łączy się również z głębokim szacunkiem do wszystkiego, co stanowi o wartości innych narodów. Wymaga uznania i przyjęcia wszelkiego dobra znajdującego się poza człowiekiem i gotowości do moralnego doskonalenia się w oparciu o dorobek i doświadczenie innych narodów. Siłą twórczą prawdziwego patriotyzmu jest więc autentyczna miłość, wolna od nienawiści, bo nienawiść to mur, który oddziela człowieka od człowieka w narodzie. Postawa nienawiści niesłychanie zuboża własny naród, pozbawiając go możliwości korzystania z dorobku całej ludzkiej rodziny ${ }^{30}$. Miłość ojczyzny,

28 J. Bajda, Feministki, papież i Europa, dz. cyt., s. 37-38.

29 Por. J. Bajda, Wokół pewnego sporu, dz. cyt., s. 93-94.

30 Por. Konferencja Episkopatu Polski, List Episkopatu Polski o chrześcijańskim patriotyzmie, w: Listy pasterskie Episkopatu Polski 1945-1974, Paryż 1975, s. 707-708. 
która rodzi nienawiść, fanatyzm i niesprawiedliwość wobec innych narodów, nie jest niczym innym, jak tylko zwyrodniałą stronniczością. Trudno mówić o zdrowym patriotyzmie, jeśli się nienawidzi inne narody. Chrześcijańskie pojęcie miłości ojczyzny jest dalekie od szowinizmu, ksenofobii oraz nacjonalizmu i kosmopolityzmu, który marzy o wszystkich narodach i całej ludzkości, a nie chce pracować dla tego, co najbliższe - dla swej ojczyzny ${ }^{31}$.

Mówiąc o odpowiedzialności za ojczyznę, ks. Bajda często przypominał i wskazywał na potrzebę nieustannego nawracania się z licznych grzechów i wad narodowych. Do najbardziej niebezpiecznych zaliczał: alkoholizm, narkomanię, demoralizację dzieci i młodzieży, korupcję oraz kryzys życia małżeńsko-rodzinnego. Wszystkie te słabości - zdaniem ks. Bajdy - poważnie zagrażają prawidłowemu rozwojowi kraju. Prawdziwa miłość ojczyzny wymaga więc od wszystkich nieustannej pracy nad sobą i walki z nałogami i wynaturzeniami. Jest to istotne zadanie moralne, które należy podjąć nie tylko dla pomyślności ojczyzny, ale i prawidłowego rozwoju życia chrześcijańskiego człowieka. Praca nad sobą, nad swoimi wadami wymaga wielu wyrzeczeń i cierpliwości. Odniesione zwycięstwo daje jednak wielką radość i pokój. Przynosi szczęście człowiekowi i pożytek ojczyźnie.

Według ks. Bajdy prawdziwa miłość ojczyzny domaga się również dzisiaj odważnego reagowania indywidualnego i poprzez organizacje pozarządowe na pedagogikę permisywną w szkołach, niekonieczną pracę w niedzielę, złe treści przekazywane w mass mediach itp. Zarazem trzeba mocno podkreślić, że nie wolno się lękać wpływów z zewnątrz. Lęk byłby to dowodem takiej samej niedojrzałości, jak postawa odrzucania z góry wszystkiego, co rodzime. Nie chodzi o lęk przed nowością, ale o lęk przed złem. I nie chodzi o upieranie się przy tym, co było dotychczas, ale o budowanie takiej atmosfery w ojczyźnie, żeby - na ile to możliwe - każdy człowiek czuł naprawdę u siebie ${ }^{32}$.

\section{Formacja patriotyczna}

Niezwykle ważnym zadaniem moralnym w obecnej polskiej rzeczywistości jest wychowanie do właściwie pojętej miłości ojczyzny. Człowiek prawdziwie

31 Por. A. Lepa, O patriotyzmie w mediach „Wychowawca” 4 (2003), s. 12. Por. także: H. Łuczak, Wierność dziedzictwu, Lublin 1985, s. 121.

32 Por. J. Salij, Patriotyzm dzisiaj, Poznań 2005, s. 20-21. 
kochający ojczyznę, poznający jej historię, kulturę, religię, angażujący się w budowanie jej pomyślności, staje się człowiekiem pokoju i wysokiej kultury, prawym i odpowiedzialnym obywatelem narodu. Zdawał sobie z tego sprawę ks. prof. Bajda, dlatego tym zagadnieniom poświęcił wiele miejsca, zwłaszcza w swoich felietonach publikowanych na łamach „Naszego Dziennika”.

Według ks. Bajdy wychowanie patriotyczne dokonuje się głównie w domu rodzinnym. Dom rodzinny odgrywa fundamentalną rolę w wychowaniu na wszystkich płaszczyznach, w tym szczególną w wychowaniu do miłości ojczyzny. „Rodzina - uświadamiał ks. Bajda - jest źródłem istnienia i żywotności narodu" 33 . $Z$ domu rodzinnego młody człowiek powinien wynieść pierwsze fascynacje ojczystym językiem, kulturą, tradycją, historią ${ }^{34}$. Zanikające już dziś wielopokoleniowe rody stwarzały warunki do tworzenia specyficznej atmosfery, która kładła podwaliny pod budzenie się uczuć narodowych. Dziadkowie opowieściami o dawnych dziejach zaszczepiali poczucie więzi z przodkami. Łatwiej było wówczas zrozumieć młodym, ile zawdzięczają przeszłym pokoleniom. W rodzinie powinno uczyć się pierwszych modlitw i kształtować podstawy głębokiej religijności. Nauka pacierza, podstawowych prawd wiary, kultywowanie typowo polskich tradycji świątecznych ma ważne znaczenie dla formacji religijno-patriotycznej dzieci i młodzieży.

Można więc powiedzieć - przytaczając słowa ks. Bajdy - że istnienie narodu zależy od tego, czy serca ojców i matek są tak szerokie i bogate, aby pomieścić całą treść narodowego dziedzictwa i duchowej tradycji przodków żyjących heroiczną wiarą, aby ten posag przekazać młodym, otwierającym oczy i umysły na odczytanie sensu świata; czy blask miłości ojcowskiej sięga tak daleko w przestrzeń duchową narodu, by wszystko, co oświeca, mogło objawić się w oczach młodego człowieka jako Ojczyzna, wspólny dom wszystkich jego braci ${ }^{35}$.

33 J. Bajda, Rodzina miejscem Boga i człowieka..., dz. cyt., s. 155. Por także: J. Bajda, Rozpad „,humanizmu" oświeceniowego czy ", katastrofa antropologiczna", "Sprawy Rodziny" 73 (2006) nr 1, s. 90.

34 Por. J. Bajda, Znaczenie rodziny dla kultury, w: Teologia, kultura, współczesność, red. Z. Adamek, Tarnów 1995, s. 41-62.

35 J. Bajda, Prawa narodu a prawa rodziny, w: Obrona i promocja rodziny. Zamyślenia Księdza Profesora Jerzego Bajdy..., dz. cyt., s. 66-67. 
Wychowanie patriotyczne to także kształtowanie cnót obywatelskich, czyli zachowań, w których przejawia się troska o ojczyznę, realizuje się konkretne poczucie odpowiedzialności za jej rozwój. Ważną cnotą jest ofiarność, bez której nie ma pozytywnego stosunku do ojczyzny i jej spraw. Dom rodzinny ma być miejscem, gdzie wyrabia się w dzieciach umiejętność podejmowania wyrzeczeń na rzecz innych, gotowość do ofiar ${ }^{36}$.

Z cnotą ofiarności łączy się cnota wierności, która przejawia się w wytrwałej, wiernej służbie dla państwa, rzetelnym wypełnianiu obowiązków obywatelskich. Do cnót obywatelskich należy zaliczyć pracę i pracowitość. Poprzez pracę człowiek urzeczywistnia swoją godność, staje się bardziej człowiekiem $^{37}$. $\mathrm{Z}$ tego powodu praca łączy się z wychowaniem, a zarazem z rodziną, która jest jej pierwszą szkołą. „Pracując, człowiek współpracuje z Bogiem i z ludźmi i tak tworzy dobro powszechne: dobro rodziny, narodu, państwa"38. Do istotnych cnót obywatelskich ks. Bajda zaliczał również tradycyjne polskie cnoty, z których na szczególną uwagę zasługuje gościnność i pietyzm wobec tego, co ojczyste, polskie. $Z$ tego wynika, jak wielkie pole do działania mają wychowawcy, a zwłaszcza rodzice, gdyż to oni są głównymi przekazicielami wartości i postaw patriotycznych ${ }^{39}$.

Zdaniem ks. Bajdy ważne zadanie w wychowaniu do miłości ojczyzny ma do spełnienia polska szkoła. Szkoła kontynuuje i ubogaca wychowanie patriotyczne wyniesione $\mathrm{z}$ domu rodzinnego, kształtując poczucie odpowiedzialności za ojczyznę, za wszystko, co ją stanowi. Do głównych zadań szkoły należy formowanie intelektualne, a przez to utrwalanie postaw patriotycznych. Najważniejszą rolę odgrywają takie przedmioty, jak: historia, język polski, geografia i przyroda (biologia), muzyka, wiedza o społeczeństwie. Historia łączy wolę przeszłych pokoleń $\mathrm{z}$ obecną ${ }^{40}$. Literatura - poprzez ukazywanie losów bohaterów narodowych - motywuje do naśladownictwa, a także uczy piękna rodzimej mowy. Geografia i biologia ukazują wyjątkowość przyrody i krajobrazu polskiego (pomocne są w tym zakresie wycieczki krajoznawcze). Wychowanie muzyczne uwrażliwia na piękno rodzimej tradycji w tym zakresie. Wiedza o społeczeństwie powinna wskazywać

36 Por. J. Bajda, Rodzina miejscem Boga i człowieka..., dz. cyt., s. 152.

37 Por. Jan Paweł II, Enc. Laborem exercens" (1981), nr 76.

38 S. Wyszyński, Duch pracy ludzkiej, Warszawa 1957, s. 38.

39 Por. J. Bajda, Etos rodziny fundamentem społeczeństwa ,Z Pomocą Rodzinie” 5 (1990), s. 12-23.

40 Por. Z. Balicki, Zasady wychowania narodowego, Warszawa 1909, s. 4-5. 
na główne zadania życia narodowego w dobie obecnej. Ważną rolę w szkolnym wychowaniu patriotycznym odgrywają również uroczystości patriotyczne, pogadanki wychowawcze oraz ogólna dyscyplina, która sprzyja formowaniu prawych charakterów ${ }^{41}$.

Pielęgnowanie katolickiego nurtu w kulturze narodowej w głównej mierze należy do zadań Kościoła. Ks. Bajda uświadamiał, że czasie zaborów, a także w okresie komunizmu Kościół nie tylko prowadził do Chrystusa, ale też był ostoją polskości. W czasach liberalizmu i postmodernizmu zmuszony jest w dalszym ciągu spełniać te zadania. Tak się składa, że wróg katolicyzmu jest najczęściej wrogiem Polski. Liberalizm podobnie jak komunizm usiłuje zniszczyć wiarę, wartości moralne wypracowane przez wieki i równocześnie godzi w podstawy bytu narodowego ${ }^{42}$.

W tym kontekście słuszny wydaje się skierowany do wiernych apel biskupów polskich z 14 marca 2004 roku, w którym wyrażona została troska o przyszłość Polski w perspektywie jej wstąpienia do Unii Europejskiej:

Szereg czynników sprawia, że pokolenie współczesnych Polaków stoi przed szansami, ale także i przed niebezpiecznymi pokusami, które będą się jeszcze bardziej wzmagać. A jest to nie tylko pokusa bierności i apatii, wycofania się z zaangażowania na rzecz wspólnoty czy pokusa emigracji. Znajdzie się także wielu polityków, którzy będą kusić i łudzić obietnicami bez pokrycia i fałszywymi receptami na łatwe szczęście. Nie wolno dać się zbałamucić. Nie istnieje droga na skróty do pomyślności i społecznego ładu. Im więcej wolności, tym więcej odpowiedzialności [...]. W perspektywie naszej obecności w Unii Europejskiej przed polskim społeczeństwem stoją wielkie zadania. Pomyślny rozwój Europy wymaga budowania cywilizacji życia i miłości. Tymczasem zagrożenia, także w naszej Ojczyźnie, są wielkie. Po raz kolejny podejmuje się propagandę na rzecz zabijania nienarodzonych dzieci oraz przygotowuje się programy edukacyjne sprzeczne z prawem rodziców do wychowania dzieci w duchu własnych przekonań. Ta tendencja przed kilku laty została przezwyciężona, a dzisiaj, w imię wypaczonej wizji postępu, z uporem usiłuje się do niej wracać. Nie tylko katolikom, ale każdemu, komu

41 Por. K. Chałas, S. Kowalczyk, Wychowanie ku wartościom narodowo-patriotycznym..., s. dz. cyt., 121-296.

42 Por. J. Bajda, Feministki, papież i Europa, dz. cyt., s. 35-38. 
miłe są wartości humanistyczne i ogólnoludzkie, nie wolno uczestniczyć w kształtowaniu opinii publicznej tak, by sprzyjała zamachowi na życie człowieka [...]. Apelujemy szczególnie do młodych Polaków, którzy są naszą nadzieją, by z entuzjazmem włączyli się w dzieło kształtowania oblicza Europy w oparciu o wartości chrześcijańskie ${ }^{43}$.

Formowanie charakterów wymaga zatem zwrócenia większej uwagi na środowisko, w którym dorasta młodzież. Negatywną rolę odgrywają tu tzw. subkultury młodzieżowe. Identyfikując się z tymi grupami, młodzi ludzie przejmują idee anarchistyczne i konsumpcyjne. Część tych subkultur, o zabarwieniu anarchistyczno-lewicowym, utożsamia patriotyzm z faszyzmem. Niewątpliwie potrzebą chwili jest izolowanie młodych ludzi od tego typu trendów i mód. To samo odnosi się do subkultur szerzących wzorce szowinistyczne i neopogańskie ${ }^{44}$.

Konieczna jest selekcja w wyborze programów telewizyjnych i radiowych. To samo dotyczy roztropnego czytania książek i czasopism. Szczególnie w okresie dorastania, gdy psychika jest jeszcze nieukształtowana, pojawia się realne niebezpieczeństwo przejęcia postaw antypatriotycznych, natrętnie narzucanych przez propagandę, która w życiu dorosłym może przynieść efekt w postaci „nowego, liberalnego patriotyzmu”, od którego tylko krok do zwykłego kosmopolityzmu ${ }^{45}$.

Według ks. Bajdy, aby wychowanie do miłości ojczyzny przyniosło pożądane skutki, musi oprzeć się propagandzie mediów ${ }^{46}$. W przeciwnym razie okaleczenie duchowe pogłębi się, doprowadzając w końcu do wyrzeczenia się polskości przez przyszłe generacje. Nowe pokolenia, pozbawione zakorzenienia w kulturze i historii Polski, coraz łatwiej będą akceptować różne modne idee i trendy religijne.

Ks. Bajda wielokrotnie podkreślał, że obecność Polski w strukturach Unii Europejskiej stawia nowe wyzwania dla zajmujących stanowisko wobec wartości patriotycznych. Pierwszoplanowym zadaniem wychowawczym staje

43 Apel biskupów polskich o odpowiedzialność za przyszłość Polski i Europy w obliczu wstąpienia Polski do struktur Unii Europejskiej z 18 marca 2004, s. 1-2.

44 Szerzej por.: M. Braun-Gałkowska, Patriotyzm - cnota zapomniana?, w: Szkoła miejscem kształtowania postawy patriotycznej..., dz. cyt., s. 77-90.

45 Por. J. Salij, Patriotyzm dzisiaj..., dz. cyt., s. 20-29.

46 Por. J. Bajda, Dziecko ocalić czy zgubić...? ",Sprawy Rodziny” 68 (2004) nr 4, s. 98-105. 
się budowanie wspólnoty ducha, u której podstaw leżą: godność człowieka, prawda, wolność, odpowiedzialność. Powstaje zadanie budowania ojczyzny ojczyzn. Implikuje to poszanowanie własnego narodu, ojczyzny, państwa, kultury, obyczajów, darzenie tych wartości najlepszymi uczuciami. Ale też pojawia się zadanie poznawania historii i kultury innych narodów, postrzegania różnic i wspólnych elementów po to, by bardziej „być” razem na globie ziemskim, zachowując to, co odrębne, i budując w duchu przyjaźni, integracji, zaangażowania, solidarności to, co wspólne ${ }^{47}$.

W związku z powyższym potrzebne jest formowanie ludzi o prawych i silnych charakterach. W domu i szkole jest wiele okazji do ćwiczenia obowiązkowości, pracowitości, wdzięczności, posłuszeństwa, szacunku dla własnego narodu i innych narodów. Wytrwałe kształtowanie tych cnót jest nieodzownym elementem formacji patriotycznej. Człowiek bez wypracowanych cnót społecznych nie zdecyduje się na oddanie życia za ojczyznę, nie będzie mu się nawet chciało dla niej pracować.

\section{Zakończenie}

Z powyższych rozważań wynika wyraźnie, że dla ks. prof. Bajdy ojczyzna jest obszarem powołania i moralnej odpowiedzialności, jest darem i jednocześnie zadaniem moralnym dla każdego człowieka. Każdy chrześcijanin powołany jest do tego, aby z całą gorliwością i stanowczością dbać o dobro ojczyzny i wszystkie jej potrzeby. Jego powinnością jest miłować ojczyznę jak własną matkę.

Ojczyzna bowiem umożliwia człowiekowi to wszystko, co jest niezbędne do ukształtowania i wzbogacenia własnej osobowości. Chrześcijanin w służbie ojczyźnie może też dostrzec jedno z wielkich Bożych wezwań prowadzących do moralnej doskonałości. Tak więc żaden uczeń Chrystusa nie może przejść obojętnie wobec tego wszystkiego, co kryje się pod pojęciem „ojczyzna"' Z obowiązku odpowiedzialności za ojczyznę nikt też nie może człowieka zwolnić. Odpowiedzialność za kraj ojczysty jest wymogiem chrześcijańskiej wiary. Tej odpowiedzialności człowiek uczy się najlepiej w rodzinie, ale kształtują ją także Kościół i szkoła. Szczególnie te trzy płaszczyzny - rodzina,

47 Por. T. Wójcik, Aktywny patriotyzm, „Wychowawca” 4 (2003), s. 17. 
szkoła i Kościół - są nieodzowne do właściwego uformowania postawy patriotycznej.

Analizując nauczanie ks. J. Bajdy, warto też zaznaczyć, iż mocno akcentował on ponadczasowe i praktyczne znacznie swego posłannictwa, które wypływało z ewangelizacyjnej misji Kościoła. Jego refleksja, naznaczona wielkim pietyzmem wobec wielowiekowego depozytu wiary, może stanowić wielki wzór klarownego wyrażania chrześcijańskich zasad moralnych, będących adekwatną odpowiedzią na te problemy, które niesie w sobie rzeczywistość życia ludzkiego, podlegająca ciągłym przeobrażeniom i różnorakim kulturowym fluktuacjom. 
